\title{
DE ORGANISATIE VAN HET BEDRIJF EN DE OPENBARE ACCOUNTANT
}

\author{
door Drs. F. D. Zandstra
}

\section{Een ruime probleemstelling}

Een van de zes onderwerpen van het Zevende Internationaal Accountantscongres 1957 - dat nu alweer enige weken achter ons ligt, maar dat de deelnemers nog lang in herinnering zal blijven - was getiteld: De organisatie van het bedrijf en de openbare accountant. Hierover zijn vijf inleidingen geschreven, t.w. door de heren F. M. Richard (Frankrijk), S. C. Bakkenist, ec. drs. (Nederland). J. E. Harris, b. com. (Verenigd Koninkrijk), Svante Kihlman, ekon. mag. (Finland) en G. L. Philippe (U.S.A.). Het „panel” dat op het Congres over dit onderwerp discussieerde, stond onder leiding van de heer $\mathrm{H}$. Reinoud - zoals bekend een autoriteit op dit gebied, getuige o.m. zijn praeadvies van 1953 1) - en bestond verder uit 8 leden, t.w. de 5 inleiders en de heren Dr. F. Boter y Mauri (Spanje), Shalom Proshan (Israel) en R. Keith Yorston (Australië).

De commissie die dit onderwerp aan de orde stelde, heeft blijkbaar de inleiders en de discussiegroep zoveel mogelijk armslag willen geven. De beide "termen" van deze relatie zijn immers zo ruim geformuleerd, dat er een hele reeks van problemen door wordt bestreken.

Voor de behandeling is het nodig om de beide termen „organisatie van het bedrijf" en .,openbare accountant" nader te .,differentieren", en dus de ruime probleemstelling te ontleden in een aantal deelproblemen.

Alvorens daartoe over te gaan, willen wij echter eerst een ogenblik stilstaan bij het feit, dat de titel van het onderwerp op zichzelf reeds - nog geheel afgezien dus van de samengesteldheid der beide termen - voor tweeerlei uitleg vatbaar is.

Elk van de twee termen kan immers dienen als uitgangspunt voor de relatie tussen beide.

\section{De openbare accountant uitgangspunt}

Stelt men zich op het standpunt van de public accountant, dan zal men de titel van ons onderwerp ongeveer als volgt interpreteren:

wat heeft de openbare accountant te maken resp. wat kan (of dient) hij te maken (te) hebben met de organisatie van het bedrijf?

Men komt dan op problemen als de betekenis van de organisatie voor de de accountantscontrole, de organisatie als zelfstandig object van controle of als object van advies voor de public accountant, enz. Zo is het onderwerp ook door vier van de vijf preadviseurs opgevat en uitgewerkt, en zo is erover gediscussieerd. Men kan erover twisten of voor deze probleemstelling de omgekeerde titel niet iets juister was geweest, maar op een Congres van accountants lijkt een andere uitleg nauwelijks mogelijk.

Wie kennis genomen heeft van de vijf uitgebrachte preadviezen zal het echter zijn opgevallen dat het vijfde afwijkt van de andere vier. De Amerikaanse inleider, G. L. Philippe, is ook niet zoals de andere vier heren in het vrije beroep werkzaam, doch controller bij éen bepaald bedrijf. (Hij is ook niet lid van een accountantsorganisatie, maar van het Controllers Institute of America). Hij heeft de organisatie van het (zijn) bedrijf als

1)..Enkele opmerkingen omtrent de toekomstige ontwikkeling van de organisatiedeskundigheid van de accountant". (De Accountant, nov. "53). Aan dit preadvies wijdde het NIVA twee studievergaderingen (Verslagen in De Accountant van jan. en mei '54.) 
uitgangspunt genomen, en is na een beschrijving daarvan ingegaan op de vraag welk nut de public accountant voor dat bedrijf heeft.

Hoewel deze bijdrage weinig bevat over ons eigenlijke onderwerp, dus ook niet laat zien wat de Amerikaanse public accountants te dien aanzien denken en doen, zouden wij haar toch niet gaarne uit de bundel willen missen, omdat zij een aantal interessante ,,side-lights" geeft. Enkele daarvan willen wij hier even naar voren brengen.

\section{Het zeer grote bedrijf en de openbare accountant}

In de aanvang van zijn inleiding noemt de heer Philippe enkele kenmerkende cijfers over het bedrijf waar hij de controller-functie vervult: General Electric Company. Deze onderneming maakte in 1956 een omzet van 4 milliard dollar, had ongeveer 280.000 mensen in dienst, terwijl zij eigendom is van meer dan 360.000 aandeelhouders.

Het is begrijpelijk dat de schrijver zelf geen vergelijkingen maakt met andere grote bedrijven in de Verenigde Staten. Raadpleegt men „The Fortune Directory" (jaarlijkse uitgave van het bekende Amerikaanse maandblad Fortune) van juli 1957, dan blijkt dat General Electric op de lijst van ,the 500 largest U.S. industrial corporations" in 1956 de 5 de plaats bezette. Dit is dan de rangschikking naar omzet. De lijst bevat nog een aantal andere rangschikkingscijfers. Naar aantal aandeelhouders is G.E. (zoals het bedrijf in de wandeling heet) no. 3, en naar aantal employés zelfs no. 2 (alleen overtroffen door General Motors, dat 600.000 man personeel telde). 2 )

Phillippe beschrijft dan in korte trekken de administratieve organisatie (hij spreekt zelf van: financial organization) van dit enorme bedrijf. Enorm zijn ook de problemen waarvoor men hier wordt gesteld, maar, zo zegt hij, wij beschikken over een staf van eersterangs administrateurs, interne accountants en controllers, die capabel zijn om deze poblemen op te lossen. Kunnen externe accountants nu nog van nut zijn in een bedrijf met zulk een "galaxy of top accounting talent"?

Dit blijkt wel degelijk het geval. Vooropstellende dat dit nut primair ligt in de onafhankelijkheid van de public accountant, gaat de auteur vervolgens diep in op de betekenis van ...... de accountantscontrole voor een bedrijf als het zijne (met 360.000 aandeelhouders).

Deze bladzijden zijn buitengewoon interessant, maar voor ons eigenlijke onderwerp zijn zij toch slechts zijdelings van belang. Wel wijst de schrijver erop dat, zelfs bij een bedrijf als G.E., de public accountant waardevolle adviezen kan geven $m$.b.t. het systeem van de interne controle. Maar voor het overige is de enige zinsnede, die met het oog op ons onderwerp onderstreept moet worden, die aan de voet van blz. 59: ,To the smaller concern, the public accountant is a valued business counselor whose view from the outside and whose wide knowledge of business skills are very helpful". Men vraagt zich daarbij dan echter wel af, wat déze auteur bedoelt met een "smaller concern". Een bedrijf met een omvang van b.v. $5 \%$ van G.E. - en 1 op 20 is toch een sterke ,,verkleining" - zou altijd nog circa 14.000 man personeel tellen, en dus, zeker voor ons begrip. nog behoren tot de grote bedrijven.

2) Wij kunnen niet nalaten om nog enkele cijfers uit deze „Directory" te citeren, niet alleen ter nadere vergelijking, maar ook om te laten zien dat ons land eveneens grote ondernemingen kent. No. 1 en no. 2 van de dit jaar voor het eerst gepubliceerde lijst van "the 100 Largest Foreign Industrials" zijn resp. de ,Koninklijke" Shell (omzet 61/2 milliard dollars; 250.000 employé's) en Unilever (omzet 4,68 milliard; personeel 121.000). Philips bezet naar omzet de 11 de plaats, maar naar het aantal employé's de 3 de (152.000). 
In de laatste alinea van zijn inleiding - onmiddellijk volgend op de zojuist geciteerde - wijst de schrijver dan nog op het nut van de public accountant als adviseur bij bizondere financiële problemen (b.v. fusie, stocksplit, invoering LIFO systeem), bij gecompliceerde belastingvraagstukken, e.d., waarbij zijn brede ervaring geeft ,a valued test of the procedures and recommendations our own staff has developed".

Hierna volgen dan nog twee zinnen die bizondere betekenis hebben omdat $z$ ij afkomstig zijn van de controller van een der grootste bedrijven ter wereld: "Other times we are merely seeking someone who understands our business and background with whom we can talk over our problems. I know that our public accountant's viewpoint and mature judgment has been of great personal benefit and reassurance to me."

\section{Indeling van de organisatie van het bedrijf}

Gaan wij thans dieper in op de behandeling van het onderwerp ,de organisatie van het bedrijf en de openbare accountant", dan moeten wij - zoals hierboven onder 1 . reeds werd opgemerkt - de beide elementen van deze relatie nader verbizonderen. Wij doen dit in het voetspoor van de discussie-leider, de heer $H$. Reinoud.

In zijn (Engelse) inleiding tot de eerste vraag, die aan het panel werd voorgelegd, maakte de heer Reinoud t.a.v. het begrip ,.de organisatie van het bedrijf" de onderscheiding:

a. de administratieve organisatie (the accounting organization);

$b$. de overige organisatie (the rest of the organization).

Aan niet-vakgenoten zal de onder $b$. gebruikte terminologie wellicht wat vreemd voorkomen, voor een gedachtenwisseling tussen accountants bleek deze onderscheiding zeer doelmatig. De taken en bekwaamheden van de public accountant zijn immers t.a.v. beide terreinen verschillend. In een aantal gevallen zou men onder $b$. misschien ook kunnen lezen: de organisatie in het algemeen.

T.a.v. het onder a. bedoelde terrein bleek behoefte aan nog een nader onderscheid: 1. financial accounting system; 2. management accounting system. Ook zonder dat de verschillende begrippen scherp en precies omlijnd werden, bleek ook deze tweede onderscheiding zeer geschikt om de gedachten te bepalen, hetgeen voor een internationale gedachtenwisseling uiteraard van het grootste belang is. Overigens mag niet onvermeld blijven dat één panel-lid, de Australiër Yorston, het nut van dit onderscheid in twijfel trok.

Onder ,.management accounting" moet worden verstaan de administratie in haar functie van ondersteuning van het bedrijfsbeheer. Men heeft hierbij in het bizonder te denken aan .,budgetary control" 3 ), aan tussen. tijdse resultatenbepaling, e.d. Het is een vraagpunt of de kostprijsadministratie op zichzelf ook onder management accounting moet worden begrepen (F. M. Richard doet dit wel; J. E. Harris niet), maar zeker is dat zij er belangrijke bouwstenen voor levert. Toetsing van de bedrijfsuitkomsten aan vooruit vastgestelde normen - zodanig ook dat de verantwoordelijkheid voor afwijkingen kan worden vastgesteld - is er een essentieel element van.

Bestond er dus behoefte om de ",administratieve organisatie" op de bovenbeschreven wijze nader in te delen, vermeldenswaard is het dat een

3) Het begrip ,control" is bizonder moeilijk in het Nederlands te vertalen. Het verschil met het Nederlandse begrip .,controle" kan, naar wij menen, niet beter worden aangeduid dan met de volgende zinsnede uit een Amerikaans boek over .,controllership”: You can't control the past.

m a b blz. 398 
dergelijke noodzaak t.o.v. de ,overige organisatie" niet werd gevoeld. In de preadviezen en in de discussie is de vraag in hoeverre de public accountant dit gebied kan en mag betreden vooral van de principiële zijde bezien. Aan een nadere indeling van dit uitgestrekte gebied is men niet of nauwelijks toegekomen. Daarvoor ontbrak in de discussie de tijd, en in de inleidingen - welker omvang beperkt was - de ruimte.

\section{De functies van de openbare accountant}

Ook m.b.t. de tweede factor uit de relatie, "de openbare accountant", bleek nader onderscheid nodig, en wel naar de functies die de accountant vervult of vervullen kan.

Daarbij hield men het op het onderscheid tussen de public accountant als ",auditor" (ten behoeve van aandeelhouders, of ruimer: het maatschappelijk verkeer) en als ,,adviser to management", hetgeen wij hieronder kortweg willen aanduiden resp. met controlerende en adviserende functie.

De enige inleider die dieper inging op de analyse van de functies van de accountant, was de Nederlander, Drs. S. C. Bakkenist. Hij baseerde zich (p. 19 van de bundel preadviezen) op de indeling van Prof. A. M. van Rietschoten, die naar de mening van de preadviseur wel algemeen door de Nederlandse beroepsgenoten wordt aanvaard. Bij deze indeling wordt naast de beide zojuist genoemde functies nog een derde onderscheiden, n.l. die van controleur ten behoeve van de bedrijfsleiding. Deze functie is op het Congres echter niet verder besproken.

\section{Vier deelproblemen}

De twee-deling van het organisatie-terrein en de onderscheiding der beide hoofdfuncties van de public accountant leiden samen tot 4 combinaties, die naar wij menen zeer geschikt zijn voor een rubricering van de vele problemen, die onder de titel ,de organisatie van het bedrijf en de openbare accountant" in de pre-adviezen en in de discussie zijn behandeld.

Deze rubricering luidt dan:

I. Controlerende functie en administratieve organisatie.

II. Controlerende functie en de overige organisatie.

III. Adviserende functie en administratieve organisatie.

IV. Adviserende functie en de overige organisatie.

Deze opsomming makt wel duidelijk hoe breed de probleemstelling was opgezet; bijna elk onderwerp zou op zichzelf voldoende stof bieden voor een werkzitting. Aan de inleiders is uiteraard wel een nadere analyse van de probleemstelling ter overweging voorgelegd. Maar dit heeft niet - zoals te verwachten was, en zelfs de bedoeling zal zijn geweest - tot parallelle uitwerkingen geleid. Ieder heeft accenten gelegd waar hij dat, al naar gelang van zijn persoonlijk inzicht en de situatie in zijn land, meende te moeten doen.

Men kan zich nog afvragen of de verschillende pre-adviezen soms bepaalde van de zojuist opgesomde vier deelproblemen hebben geaccentueerd. Wij menen dat hier inderdaad wel enig verband valt te leggen. Onder het voorbehoud dat elk preadvies veel te rijk aan inhoud is om het precies in een vakje in te passen, zouden wij willen zeggen:

Probleem I heeft niemand's speciale aandacht gehad.

Probleem II is het vraagstuk dat vooral de heren Harris en Kihlman heeft beziggehouden, waarbij zij tot tegengestelde meningen zijn gekomen. 
Probleem III zou als titel kunnen dienen van het preadvies van de heer Richard.

Probleem IV heeft de bijzondere aandacht gehad van Drs. S. C. Bakkenist.

Dat de inleiding van de Amerikaanse controller Phillippe een geheel afzonderlijke plaats inneemt, bleek hierboven reeds in paragraaf 2 en 3 .

\section{Controlerende functie en administratieve organisatie}

Dat een goede administratieve organisatie van de grootste betekenis is voor de accountantscontrole, wordt door elke accountant onderschreven. Daarbij wordt dan in het algemeen gesteld, dat er aan bepaalde minimumeisen voldaan moet zijn. Deze eisen liggen dan met name op het gebied van de "financial accounting". Alle panel-leden waren het er verder over eens - aldus de heer Reinoud, toen hij bij de aanvang van de zitting aangaf waarom over dit punt niet gediscussieerd behoefde te worden - dat de accountant ook volledig capabel is om in het geval er gebreken mochten zijn, de organisatie op dit punt te verbeteren.

Gaat men echter een stap verder en betrekt men ook het ,management accounting system" in het beeld, dan wordt er anders gedacht. Niemand gaat zo ver om de aanwezigheid van zulk een systeem als voorwaarde voor de controle te stellen. Wèl kan de controlerende accountant er voor zijn controle een groot gemak van hebben, kan het zijn controle verstevigen, alsook vereenvoudigen en - zoals de discussieleider het formuleerde - efficiënter maken.

Werpt men ook hier de vraag op of de accountant in staat geacht mag worden om zulk een systeem te organiseren - dus bijv. een budgeterings. systeem in te (doen) voeren - dan lopen de antwoorden uiteen. De heren Richard en Bakkenist meenden van wel, de Engelsman Harris betwijfelde het. Wij komen hierop straks, onder het gezichtspunt van de adviserende functie, nog nader terug.

Ter discussie werd voorts nog de vraag gesteld of de openbare accountant in het algemeen capabel geacht wordt om de efficiëntie van de administratieve organisatie te beoordelen. Weliswaar was bij deze vraag bedoeld beoordeling als apart object van onderzoek, dus los van de controlerende functie, maar de meeste debaters legden hier wel verband.

Alle sprekers waren van oordeel dat de accountant daartoe capabel is (ook de heer Harris: ,....... it is easier to appraise something than to construct it"). De Amerikaan Phillippe wees op het verschil tussen de grote organisatie en de kleinere. $\mathrm{Bij}$ de eerste zou een speciale opdracht nodig zijn, bij de tweede kan zulk een beoordeling deel uitmaken van de reguliere controle. De Israëliër Proshan daarentegen meende dat het geen deel van de ,audit" behoort te zijn.

De Nederlander Drs S. C. Bakkenist had op dit punt een zeer belangwekkende beschouwingswijze. Wanneer de accountant te dien aanzien deskundig is, dan behoort hij er ook op toe te zien dat de administratieve organisatie voldoet - en ook blijft voldoen bij veranderingen op dit gebied aan de te stellen eisen. De opdrachtgever zal dat in vele gevallen ook van hem verwachten; in geval van een ernstige tekortkoming zou hij zijn accountant erop aanzien. De Nederlandse accountants zijn dan ook geneigd, aldus de mening van de heer Bakkenist, dit tot hun taak te rekenen.

\section{Controlerende functie en de overige organisatie}

Is de controlerende public accountant verplicht om ook de rest van de m a b blz. 400 
organisatie - dus in feite de organisatie in haar geheel - te beoordelen? Deze vraag heeft een belangrijk deel (naar schatting ongeveer $2 / 5$ ) van de discussie opgeëist, terwijl tevens gezegd kan worden dat hierover het debat het felst is geweest.

De voornaamste woordvoerders waren de inleiders J. E. Harris (Engeland) en Svante Kihlman (Finland).

In het Verenigd Koninkrijk, zo deelde de heer Harris mede, is de accountant daartoe niet verplicht, en doet hij ook geen poging in die richting. Naar de mening van deze spreker zou de accountant er ook nooit toe verplicht mogen worden. Natuurlijk zijn er wel enige grensgevallen, nl. als iets zo slecht georganiseerd is dat de accountant niet tot een goedkeurende verklaring kan komen (b.v. magazijnbeheer). Maar in het algemeen geldt dat het de directie (,management"; opperste leiding) is die heeft uit te maken hoe het bedrijf georganiseerd en geleid wordt. $Z_{i j}$ is door de aandeelhouders belast met de verantwoordelijkheid voor de bedrijfsvoering, en deze verantwoordelijkheid zou door een controle als bovenbedoeld - let wel: in de gedachtengang van Harris een door de wet voorgeschreven controle ten behoeve van aandeelhouders - aangetast worden. De directie zou telkens in de positie komen dat zij haar beleid tegenover aandeelhouders zou moeten verdedigen, terwijl zij dikwijls moeilijk alle overwegingen die het beïnvloed hebben, kan verstrekken. Er zijn trouwens nauwelijks objectieve maatstaven voor een dergelijke beoordeling te vinden. Dikwijls zijn er meerdere wegen die naar Rome leiden. Tenslotte is er maar één manier om het beleid te beoordelen: aan de financiële resultaten. ,To summarize", zo kan men uit het preadvies van de heer Harris citeren, ,the public accountant in his capacity as auditor is called upon to report on what has happened and not to give advice or to say what might have happened if an alternative set of circumstances had been in existence" (p. 43).

Natuurlijk kan, zo voegde Harris in de discussie hier nog aan toe, de accountant wel een persoonlijk oordeel hebben over de efficiency van het bedrijf, en kan het uiterst nuttig zijn om dit aan de directie kenbaar te maken. Maar dan in een andere positie dan als auditor die de (in Engeland) door de wet voorgeschreven controle t.b.v. aandeelhouders verricht.

Met dit standpunt van de theoretische en practische onjuistheid van een ",management audit" waren de heren Richard, Phillippe en Yorston het volledig eens. De Amerikaan wees er op dat de public accountant natuurlijk bevoegd is ,in the accounting area" maar dat ,in the other areas perhaps a little knowledge is a dangerous thing ......"

De Fin Kihlman stelde daar tegenover dat in zijn land (evenals in $Z$ weden) de accountant eenvoudig bij de wet - reeds sinds 1895 - verplicht is om behalve de "räkenskaper" van een bedrijf (d.i. de administratie en de jaarrekening) ook de "förvaltning" (management) te onderzoeken en in zijn verklaring te begrijpen. De accountant is verplicht "to form an opinion of the business organization in its entirety" (voor uitvoeriger weergave zie preadvies).

Maar, zo vroeg de heer Harris, is deze verantwoordelijkheid nu beperkt tot zwakke plekken in de interne controle, e.d., strekt zij zich uit tot tekortkomingen die ,any normal business man" kan constateren, of gaat zij verder: geeft de accountant zijn oordeel als expert? Kihlman's antwoord hierop luidde: het reikt zover als de persoonlijke bekwaamheid van de accountant. Het gaat er vooral om of de directie niet iets onwettigs of ontoelaatbaars - „maar hoever reikt dat?" vroeg Phillippe - doet. Op de 
vraag van de Iraëliër Proshan of in Finland of $Z$ weden ooit een accountant in rechten is vervolgd wegens verzuim te rapporteren over slecht beleid of wegens onjuiste critiek, antwoordde $\mathrm{K}$. dat dit nooit gebeurd was, en dat dit ook niet spoedig te verwachten was, omdat men toch iemand moeilijk kan vervolgen voor het feit dat hij een bepaalde mening heeft (mits deze berust op een controle, die op redelijke wijze is geschied).

Het Spaanse lid van het panel, Dr Boter, was van mening dat de deskundigheid van de accountant nooit zo breed en uitgestrekt kon zijn _., universalisten, zoals de Middeleeuwen die kenden, zijn niet meer mogelijk" dat hij tot zulk een oordeel in staat is. Maar Kihlman schrijft in zijn inleiding (p. 46): ,.It is not thus expected that he shall be an all-round expert with greater qualifications in all spheres than everybody else ....." en even verder ,....... one has knowledge of the accountant's general qualifications".

De heer Yorston sprak, schertsend, de hoop uit dat de Zweeds-Finse "Company Acts" nooit in het Engels vertaald zouden worden, en ook Phillippe was het ermede oneens. Zo stond de Finse accountant vrijwel alleen, maar hij kon zich troosten met de opmerking van de discussieleider dat de Fins-Zweedse opvattingen zeker nader bestudeerd verdienen te worden.

Vergissen wij ons niet dan moet menig accountant, die deze discussie beluisterde, het gevoel gehad hebben dat het verschil in opvatting niet zo groot was als het leek. En menig Nederlands accountant zal hebben gedacht aan de discussie die in vroeger jaren in ons land is gevoerd over de vraag in hoeverre de accountant ,,bemoeienis heeft met het bestuur" zoals Prof. Limperg het formuleerde ${ }^{4}$ ).

\section{Adviserende functie en administratieve organisatie}

Dat de public accountants een belangrijke taak hebben m.b.t. het verbeteren van de administratieve organisatie der bedrijven, wordt door vrijwel alle preadviseurs en panelleden onderschreven.

Wij hadden reeds gelegenheid erop te wijzen dat de Engelsman Harris betwijfelde of de gemiddelde public accountant in staat is om een ,management accounting system" in te voeren. Zijn opleiding en ervaring zijn anders gericht, zo meende $\mathrm{H}$., het controle-werk eist hem praktisch geheel op, en hij is er misschien ook psychologisch minder geschikt voor. Maar het is natuurlijk mogelijk, aldus voegde hij eraan toe, dat kantoren of individuele accountants zich in deze richting specialiseren (Preadvies, p. 43 en 44).

In deze opvatting stond de heer Harris echter vrijwel alleen. De Australiër Yorston wees er in de discussie op, dat een ontwikkeling in de hier besproken richting wel nodig is, wil de praktiserende accountant niet ,be left purely with the green ink and the auditing".

De Nederlandse preadviseur Drs S. C. Bakkenist sprak uitdrukkelijk de mening uit dat dit gebied binnen de deskundigheid van de accountant (zij het misschien niet van elke individuele accountant in dezelfde mate) valt. T.a.v. de administratieve organisatie in het algemeen, waaraan de heer Bakkenist een van de belangrijkste paragrafen van zijn preadvies wijdt, concludeert hij (p. 21) ,,Hier ligt voor de public accountant een belangrijk werkterrein. De bedrijven hebben dringend behoefte aan deskundige voor-

4) Voor een korte samenvatting van deze discussie zie de „Beknopte Encyclopedie der Accountantscontrole", onder het trefwoord "Beheer".

m a b blz. 402 
lichting." Hij wijst voorts (p. 22) op de grote betekenis van de controllersfunctie, alsook op het belang van goede bedrijfsoverzichten als indirect middel tot productiviteitsverbetering. Zeer interessant is ook het verband dat de schrijver hier legt met de controle-functie, waarbij hij o.m. wijst op de noodzaak van een heroriëntering van de controle-arbeid van de openbare accountant, voortvloeiend uit de eis van snellere berichtgeving.

De Franse preadviseur, F. M. Richard, heeft deze bizondere relatie tussen accountant en organisatie - dus het verbeteren van de administratieve organisatie - tot de centrale these van zijn inleiding gemaakt. Op blz. 6 schrijft hij: ,...... le contrôle de gestion est le domaine d'élection des professionnels de la comptabilité". Op interessante wijze schrijft hij over de ontwikkeling van de administratie tot instrument voor het bedrijfsbeheer. De administratie moet worden "dynamique et motrice" (p. 8). Zij is niet langer alleen het logboek (nautische beeldspraak is in deze geliefd; wen vergelijke ook de Amerikaanse vergelijking van de controller met de ,navigator") maar ook het instrumentenbord van het schip. En hij concludeert dat hier een grote en grootse taak voor de accountants ligt. Controllership wordt een functie in de bedrijven net zo gewoon als productie, verkoop, financiering. De grote bedrijven zullen de public accountants vragen hetzij deze "control" voor hen te organiseren, hetzij reeds bestaande „control departments" te beoordelen in vergelijking met die van andere bedrijven. Middelgrote bedrijven zullen de accountants vragen voor hen op te zetten (wij citeren de Engelse vertaling): ,forecasting, planning, budgeting, control, the appraisal of their overall organization".

Is de openbare accountant tot dit alles capabel? Het antwoord van de Franse inleider hierop luidt: de accountant kan zich specialiseren op „,controllership" (controle de gestion) of hij kan zich associëren met specialisten op zulke gebieden als: kostprijs, budgetering, statistiek en operations research, industriële, commerciële, financiële en algemene organisatie, alles op basis van de accountantsopleiding. Inzake technische problemen kan men met andere specialisten (b.v. ingenieurs) samenwerken. Maar de accountant is de aangewezen man om de synthese tussen dit alles tot stand te brengen (p. 10).

Met dit ambitieuze programma hebben wij reeds het onderwerp van deze paragraaf overschreden in de richting van dat van de volgende. Daar zal dan tevens gelegenheid zijn om enkele beperkingen te noemen, die volgens sommige andere schrijvers en sprekers verbonden zijn aan de hier besproken gebiedsuitbreiding van de public accountant.

\section{Adviserende functie en de overige organisatie}

Bijna unaniem zijn de preadviseurs van mening dat de public accountant een belangrijke bijdrage kan leveren tot de verbetering van de organisatie van het bedrijf. Zo schrijft b.v. de heer Kihlman in zijn Conclusie: ,....... the public accountant, with his knowledge and his experience, should endeavour to help the enterprise to improve its business organization". En even verder: „The business world ...... expects that the accountant shall be an adviser to a much larger extent than previously". Daarbij mag dan echter zijn specifieke taak - ,to audit" - niet in het gedrang komen.

Ook de Engelsman Harris ziet - mits zorgvuldig gescheiden van de ..statutory audit function" - mogelijkheden op dit gebied. .There has been", zo schrijft hij op p. 43 van zijn inleiding, ,in my country a further development whereby some of the larger firms of public accountants have 
set up within their organizations departments which specialize in what has become known as Management Consulting".

Beide inleiders wijden paragrafen aan dit verschijnsel.

Maar wij doen, zo menen wij, de andere preadviseurs niet tekort, wanneer wij hier vaststellen dat de Nederlandse inleider, Drs S. C. Bakkenist, het diepst ingaat op de mogelijkheden voor en beperkingen aan het optreden van de public accountant als organisatie-adviseur. Zijn gehele inleiding is juist op deze problematiek gericht, zoals duidelijk blijkt uit de titels van de laatste twee paragrafen: De deskundigheid van de public accountant en het werkterrein van de organisatiedeskundige. En: Argumenten pro en contra het betreden van het werkterrein van de organisatiedeskundige.

Wanneer binnen het accountantskantoor een volledige specialisatie van assistenten, medewerkers en vennoten ${ }^{5}$ ) tot stand wordt gebracht - waarom dit nodig geacht wordt, zal hieronder nog nader blijken - ziet schrijver zeker mogelijkheden voor de public accountant om als organisatiedeskundige op te treden. Er is een tekort aan bekwame organisatie-adviseurs en het bedrijfsleven zal het dus zeker toejuichen als de accountants daarin helpen voorzien. Een voorsprong daarbij is dat zij al contact hebben met een groot aantal bedrijven en van deze het vertrouwen genieten. Daar staat echter tegenover, zo meent de heer B., dat het bedrijfsleven niet zo spoedig aanneemt dat de accountant ook dit werk doet, behalve dan op administratief-organisatorisch gebied. Mede op grond van nog enkele andere belemmeringen, die hieronder nog kort ter sprake zullen komen, komt de heer Bakkenist tot de conclusie (p. 27): „Daarom is de kans groot, dat de organisatieafdeling van het accountantskantoor een overgangsfase zal blijken te zijn gedurende de periode, dat het vrije beroep van organisatie-deskundige nog niet tot volle wasdom is gekomen". Wel is de heer Bakkenist van mening dat deze zaak voor de kleinere en middelgrote bedrijven anders ligt. Voor deze is het ongetwijfeld voordelig wanneer zij bij hun eigen accountant steun kunnen vinden voor het oplossen van organisatorische vraagstukken, zelfs indien hun accountant zich niet op alle punten met de gespecialiseerde vakman kan meten (p. 26).

Helaas ontbreekt hier de ruimte om het betoog van de Nederlandse preadviseur uitvoeriger weer te geven, en in het algemeen om dit boeiende onderwerp (dat hier slechts onderdeel van een ruimer gesteld probleem was) goed tot zijn recht te doen komen. Wij moeten ons verder beperken tot enkele punten, meer speciaal die welke ter discussie aan de orde zijn geweest.

De eerste vraag die daar werd opgeworpen was: bezit de openbare accountant de nodige vakbekwaamheid om als organisatie-adviseur op te treden? De heer Richard was van mening dat hij zich met de nodige specialisten kan omringen, maar het merendeel der panelleden was van oordeel - aldus de discussieleider in zijn samenvatting - dat de accountant daarmee niet te ver moet gaan, en dat zijn bemoeienis met de organisatie van het bedrijf binnen de sfeer en het klimaat van het beroep moet blijven ${ }^{6}$ ).

De Amerikaan Phillippe stelde dat de accountant waardevolle bijdragen kan leveren ,on a general basis" maar adviseren op velerlei gebied zonder

5) De heer Bakkenist wijst ook op de speciale moeilijkheid, dle het beginsel van de hoofdelijke verantwoordelijkheid in dit verband meebrengt (p. 27).

6) Cf. I. N. Frisbee in zijn artikel ..Ethical considerations in rendering management services" (Journal of Accountancy, maart 1957), die waarschuwt voor het gevaar dat .,some accountants may become mere brokers in professional services". 
het nodige "spitwerk", en de vereiste achtergrond en ervaring, achtte hij niet zonder gevaren. Ook hij meende dat het voor kleinere ondernemingen anders lag.

Drs Bakkenist maakt t.a.v. de vraag naar de deskundigheid onderscheid tussen de individuele accountant en het accountantskantoor (p. 24). In de praktijk, zo stelt hij, opereert een kantoor, niet een alleenwerkend deskundige, en een kantoor kan op een breder terrein deskundig zijn. Wel is daarbij specialisatie nodig op het organisatie-advieswerk (en daarbinnen zelfs op onderdelen), omdat één persoon moeilijk deskundig kan zijn èn als controlerend accountant èn als organisatie-adviseur. Moge dit t.a.v. de theoretische scholing nog mogelijk zijn, dan zal toch de practische ervaring in een van beide richtingen tekortschieten. Bovendien vragen beide soorten werk verschillende karakters.

Wat dit laatste punt betreft hebben de preadviseurs Richard, Kihlman en Phillippe geen probleem gezien. Wel wees de Australiër Yorston in de discussie - overigens stellende: the man who is trained in accounting will make a better adviser for management consulting work - op het verschil dat de organisatie-adviseur vooruit moet kijken, terwijl de accountant meer op "historical work" is gericht. Deze mening vindt men ook bij Harris (p. 43). Hoewel hierin zeker een kern van waarheid schuilt, kan men toch de vraag stellen of hiermede de accountantscontrole - die toch niet een dood verleden betreft, maar een essentieel element is in het levende "going concern" - niet enigermate onrecht wordt gedaan. En tevens of sommige eigenschappen die de organisatieadviseur moet hebben ook de accountant niet van groot nut zijn bij de uitoefening van zijn controlefunctie.

De moeilijkheid waarop de heer Bakkenist op p. 27 van zijn pre-advies duidt, dat men als organisatie-adviseur in een accountantskantoor alleen in de maatschap kan komen als men het accountantsdiploma heeft behaald, is ook nog even in discussie geweest. Het bleek dat in de meeste andere landen een dergelijke voorwaarde geldt: partner kan alleen iemand worden die het examen heeft behaald.

Aan het bekende collisie-vraagstuk is men in de discussie niet toegekomen. In twee inleidingen is er aandacht aan besteed: door de heer Bakkenist op p. 26/27, door de heer Kihlman p. 50/51. De laatste beredeneert - in een welhaast wiskundig. maar toch niet geheel overtuigend betoog dat hier weinig gevaren bestaan. Drs Bakkenist stelt dat het moeilijk is deze factor op zijn juiste waarde te schatten. Hij wijst er nog op dat in het C.P.A.-Handbook (U.S.A.) de conclusie luidt, dat de ,independence" van de accountant niet in gevaar wordt gebracht. Overigens meent hij dat de kans op collisie tussen controlerende en adviserende taak daalt, wanneer zij door verschillende afdelingen van het kantoor worden verricht.

Tot slot van deze samenvatting van de beschouwingen over de mogelijkheden van de public accountant op organisatie-gebied, mag niet onvermeld blijven dat alle pre-adviseurs speciale melding maken van de mogelijkheden bij kleinere ondernemingen (resp. op p. 11, p. 26, p. 44, p. 52 en p. 59). Welke bedrijfsomvang zij daarbij ongeveer op het oog hebben, komt echter nergens naar voren.

\section{Enkele slotopmerkingen}

a. Wanneer wij teruglezen wat nu van de dikwijls zeer interessante betogen der pre-adviseurs in hun inleidingen, en van de - met zo veel zorg voorbereide - gedachtenwisseling op het Congres in deze nabeschouwing 
is weergegeven, dan bekruipt ons het gevoel dat wij zeer onvolledig zijn geweest. Wij moesten nu eenmaal een keuze maken.

Eén leemte willen wij echter nog gaarne opvullen. Het laatste discussiepunt was n.l. gewijd aan een actueel (in de preadviezen niet speciaal behandeld) onderwerp: het vraagstuk van de moderne, electronische .,data processing" aparatuur. Het is bekend dat dit onderwerp de discussie-leider na aan het hart ligt (Accountantsdag 1956) terwijl tevens de aanwezigheid van de controller van General Electric een gunstige gelegenheid bood. De vraag of de accountant op dit gebied een taak heeft, werd in hot algemeen bevestigend beantwoord. Deze taak zag men liggen t.a.v. de administratieforganisatorische zijde van het vraagstuk, en t.a.v. de programmering. De heer Bakkenist wees in dit verband op de noodzaak ",to re-think" de gehele administratieve procedure.

Daarna gaf de heer Phillippe enige interessante bizonderheden over toepassingen bij General Electric, en ontvouwde tenslotte een boeiend toekomstbeeld waarin elke .,manager" door het indrukken van de winsi-enverlies knop op zijn bureau de bedragen van zijn fabriek of afdeling, tot op de minuut geleden, op het televisie-scherm voor zich krijgt.

b. In zijn inleiding tot de discussie deelde de heer Reinoud mede, dat er door drie collega's vragen en opmerkingen waren ingediend. Deze zijn op het Congres niet behandeld. maar de heer Reinoud is zo vriendelijk geweest om ze ter inzage te geven. Hiervoor, alsook voor de andere inlichtingen die hij mij na het Congres heeft willen verstrekken, wil ik ham hier ten zeerste danken.

De heer Douglas Clarke uit Londen had willen betogen dat vele accountants te zeer onder de indruk komen van onbekende termen of de omvang van zeer grote opdrachten. De accountants worden al lange tijd door hun cliënten geraadpleegd in organisatorische en beleidsproblemen. Het gaat hun als de held in Molière's Bourgeois Gentilhomme die zo graag het verschil tussen proza en poëzie wil weten, en dan uitroept: ,,...... maar dan spreek ik dus al 40 jaar proza, zonder dat ik het wist".

Ook de heer Carroll, uit Dublin, ziet grote mogelijkheden. Op belastinggebied is de accountant ook geen specialist, zo stelt hij, maar hij bezit cen goede ,working knowledge". Wij moeten niet teveel tijd besteden, zo schrijft hij in zijn brief, aan de precieze bepaling waar het terrein van de accountant eindigt, en dat van de "management consultant" begint. Vergeet niet dat de accountant een groot voordeel heeft: he is in there first. Er zijn grote, onbezette gebieden voor we aan de werkelijke grens met ,management consultancy" komen.

En de heer Armstrong - firmant van een Engels accountantskantoor dat zich uitsluitend op "management accounting" heeft gespecialiseerd - had aan de zaal willen vragen: ,Wat doet gij, als public accountant, aan de efficiency van de administratie? Daar is al zoveel te doen, voor we over de rest van de organisatie gaan praten".

c. Zoals in de aanvang van deze nabeschouwing werd opgemerkt ( $\$ 2)$, is de visie van de Amerikaanse public accountant weinig naar voren gekomen. Hierin is echter op gemakkelijke wijze te voorzien. Het bekende C.P.A.-Handbook - een uitgave van het American Institute of Accountants die ook door de heer Bakkenist in het Literatuuroverzicht bij zijn preadvies is genoemd - wijdt een speciaal hoofdstuk ( $\mathrm{nr} 25$ ) aan: .,The C.P.A. as a business consultant". (Daarnaast is een afzonderlijk hoofdstuk gewijd aan 
de adviserende taak van de accountant op het gebied van de administratieve organisatie en de kostprijsadministratie). Het is hier uiteraard niet de plaats om iets uit de buitengemeen interessante inhoud mede te delen. Wij zouden echter op twee bizondere punten willen wijzen.

In de eerste plaats dient vermeld dat aan dit hoofdstuk een Appendix is toegevoegd - ..Descriptions of Consulting Services" - waarin een groot aantal organisatie-opdrachten zijn opgesomd. Hier vinden wij een poging tot concretisering en differentiëring, die duidelijk laat zien welk een enorm terrein schuil gaat achter de term organisatie-adviezen.

De tweede opmerking betreft het feit, dat een paragraaf wordt gewijd aan de vraag: ,"To what extent do CPA's now act as business consultants?" In verband met het schrijven van dit hoofdstuk 25 is n.l. een enquête gehouden onder public accountants om op deze vraag een antwoord te verkrijgen. Wij moeten weerstand bieden aan de verleiding om te citeren uit de vele resultaten die hieruit naar voren zijn gekomen. Maar wanneer men dit alles leest, komt als vanzelf de vraag naar voren of het niet mogelijk zou zijn dat NIVA en VAGA onder haar leden - volgens de ledenlijsten tezamen circa 800 accountants in het vrije beroep, verdeeld over circa 300 kantoren, wat toch ",handzame" aantallen zijn - een onderzoek instellen naar de vraag in hoeverre zij zich op organisatie-gebied bewegen.

Men zou dan uiterst belangrijke concrete en kwantitatieve gegevens verkrijgen in aansluiting op de - overigens niet minder belangrijke - principiële beschouwingen als die waarmede wij in de preadviezen en het debat ter gelegenheid van dit Zevende Internationaal Accountantscongres zijn verrijkt. 